\title{
A Europa vista por Charles-Ferdinand Ramuz: aquém e além da nação ${ }^{1}$
}

\author{
Noël Cordonier e Alain Rochat
}

Para aqueles que o consideram um escritor regionalista, Ramuz nunca teria se interessado pela Europa e teria tido apenas uma pequena visão sobre ela. Segundo eles, a Europa de Ramuz teria se resumido à história de uma pastora perdida seguindo um magnífico touro...

Além de suas aventuras, que permanecem efetivamente num território pequeno e tratam apenas de temas geralmente ligados ao mundo rural, Ramuz sempre quis depender do único espaço próximo - "Estou aqui"** - e viver à margem da sociedade e da política - "Vivi fora do mundo"*.

Esta primeira opinião não resiste nem à observação dos fatos, nem àquela dos escritos de Ramuz. Por mais que tivesse se preservado, como suíço, dos dois grandes conflitos do século XX, ele seguiu e comentou a atualidade política da Europa durante mais de cinqüenta anos, do início do século até sua morte, em 1947: "Minha vida terá sido uma vida de guerras"*. Seu diário, suas crônicas e seus ensaios reagem, segundo seu modo próprio, aos acontecimentos e aos debates de seu tempo, e sua atitude não é nem mais nem menos marginal que a da maioria dos escritores francófonos. Como eles, Ramuz comentou não só a questão das literaturas nacionais ou internacionais, o cosmopolitismo, mas também os nacionalismos da Belle Époque, as esperanças paradoxais que se depositavam na Guerra de 1914, sua destruição desde o agravamento do conflito, a revolução russa e a revolução do proletariado, o crescimento do nazismo e do fascismo, as ameaças de guerra dos anos 1930, a Segunda Guerra Mundial e a instalação da leadership americana.

Se, portanto, Ramuz falou inevitavelmente da Europa, é preciso admitir que ele a criticou de maneira bem particular.

\footnotetext{
${ }^{1}$ Comunicação apresentada no Colóquio "Europa em obras, a construção literária e cultural de um continente”, organizado pelo SESC de São Paulo nos dias 29 e 30 de maio de 2001.
}

"(Ramuz, Charles-Ferdinand. "Besoin de Grandeur". Em: CEuvres complètes, vol. 4. Lau sanne: Rencontre, 1972: 928.)

" (Ramuz, Charles.Ferdi. nand. "Taille de l'homme". Em: CEuvres complètes, vol. IV. Ob cit.: 651.)

" (Ramuz, Charles-Ferdinand. "Journal". Em: CEuvres complètes, vol. 5. Lausanne: Rencontre, 1972: 1144.) 
Efetivamente, em conformidade com sua poética, que requer grande atenção ao detalhe concreto e que desconfia de seu oposto, da abstração, Ramuz nunca confundiu a Europa com tema de dissertação ou de ensaio, e quase nunca falou dela como teórico ou como politólogo, nem mesmo como intelectual esclarecido ou ofendido, ao contrário, por exemplo, de Spengler, Thomas Mann, Bernanos, Unamuno ou Ortega y Gasset.

Sem poder escapar de um relato compacto e homogêneo, a visão ramuziana da Europa é indutiva, isto é, ela se constrói por pequenos toques acessórios, indiretamente, por apelos que, com elegância e atitude, o escritor faz questão de fundamentar sobre o bom senso, pretensamente terreno: precisando que a lista seguinte é uma racionalização que o próprio Ramuz teria criticado, suas anotações e reflexões indiretas conduzem a uma Europa constituída por vários níveis, entre os quais estes, que merecerão nossa atenção:

1. Ao contrário do que será para Blaise Cendrars, o continente europeu é, antes de tudo, a terra matricial em que todo indivíduo está enraizado, da qual procede e que o liga a um clima e a um país. É compreendido como uma unidade geográfica e não como uma divisão política, de tipo nacional ou estatal.

2. É apenas após essa relação essencial com o espaço que entra em cena a temporalidade. A história é secundária, pois Ramuz dá muita importância aos determinismos (que formam as raças) e pouco acredita na evolução, mais exatamente, no progresso.

3. Entre os critérios que definem o indivíduo, o da língua é um dos mais importantes. Mediante algumas diferenças que ele mostra, o francófono Ramuz pensa a Europa valendo-se mais do ponto de vista da cultura francesa que de sua cidadania suíça. Em conformidade com esse espírito francês, ele imagina uma espécie de confraria internacional dos artistas, que sua atividade põe em comunicação, para além das diferenças lingüísticas, religiosas ou outras.

4. Mas o passaporte suíço de Ramuz merece também um julgamento, apenas porque as questões que ele dedica à sua pátria política anunciam as redefinições atuais da nação.

Propomos desde já percorrer estes quatro planos, misturando-os um pouco, pois sua separação absoluta é impossí- 
vel. Começaremos pelo país no sentido físico. Além de sua contribuição específica à questão da Europa, o estudo do país geográfico e simbólico nos permitirá citar alguns excertos da criação literária de Ramuz e precisar sua poética. É uma prévia indispensável, pois o Ramuz político se autoriza a pensar apenas através de e por meio dessa poética. O julgamento de alguns fragmentos textuais deveria também nos conceder um pequeno prêmio de prazer estético, tamanhas a originalidade e a densidade da língua e da escrita de Ramuz.

Mais políticos, os níveis seguintes não deveriam mascarar as ambigüidades e as incertezas do escritor, nem seus períodos, ora próximos de um nacionalismo obtuso, ora, ao contrário, quase projetados contra sua vontade em direção às atitudes que parecem anunciar os debates atuais em torno do pertencimento nacional. Efetivamente, levando-se em conta a cidadania suíça, procurar-se-á mostrar que o sedentário que ele foi paradoxalmente emitiu opiniões às vezes pouco enraizadas na nacionalidade.

\section{1) O “país" percebido}

\section{a) Uma epistemologia fenomenológica}

Escolhemos considerar em primeiro lugar o texto narrativo de Ramuz. Efetivamente, é em sua estética que se justifica a atitude do autor diante dos acontecimentos de sua época e que ele refletiu sobre as questões de identidade, nacionais ou internacionais. Criação distante, que Ramuz procura não somente evidenciar, mas também trabalhar, em particular no período central de sua atividade, dos anos 1915 a 1925 . Privilegiamos esse período por nos parecer que os textos então publicados "soam" hoje de maneira notavelmente moderna e são a expressão mais perfeita do estilo de Ramuz.

Desde 1915, desprendendo-se pouco a pouco do realismo, Ramuz empreende, a princípio de forma bastante confusa, uma pesquisa estilística original. Baseado em sua atividade de contador, ele tenta criar textos curtos que não sejam mais "histórias", como chamou alguns de seus contos, mas uma espécie de misto entre o conto e o poema em prosa. Os textos dessa época, denominados freqüentemente "fragmentos", tomam emprestado do conto alguns traços do texto narrativo (um ou mais personagens nomeados, um esboço, 
(Ramuz, Charles-Ferdinand. "Salutation paysanne". Em: CEuvres complètes, vol. 3. Lau sanne: Rencontre, 1972 375.) mais ou menos desenvolvido, de intriga, normalmente mínima, passagens de narrativa, um narrador, que se funde às vezes à voz de um dos personagens ou à comunidade à qual este pertence), utilizando bem certos procedimentos estilísticos do poema em prosa, tais como a anáfora, a repetição, os jogos de sonoridade e de ritmo, a divisão em parágrafos muito curtos, próximos dos versículos.

Em 1921, Ramuz publica uma coletânea de "fragmentos" intitulada Salutation paysanne et autres morceaux. Verdadeiro manifesto estético, esse livro, que deve ser lido de fato como um todo, apresenta várias facetas do imaginário ramuziano: não só a celebração da natureza e dos homens próximos desta, tais como agricultores, pescadores e vinicultores, mas também a descrição das atividades das aldeias e das pequenas cidades do campo. Vários desses textos põem em cena o poder do escritor e do imaginário, por meio de personagens como o caçador de toupeiras, o mendigo, ou o vagabundo, que são em Ramuz figuras do artista. Situados abaixo da escala social, marginais, sempre em contato com a natureza e a caminho dela, são pretextos para descrições e para a celebração do mundo natural e da proximidade dele.

Esses "fragmentos", geralmente no presente, procuram restituir a emoção de um curto momento e a instantaneidade de uma presença no mundo. O "personagem" não é verdadeiramente ator de uma história, mas incorpora um tipo de pessoa e de profissão em um determinado ambiente. Ramuz procura demonstrar sua percepção das coisas, dos elementos naturais, fora de toda cultura ou de todo objetivo cultural. Todos os sentidos são evocados para dar ao leitor o sentimento de uma presença, de uma epifania do mundo natural.

No texto intitulado "Le chemineau couché", Ramuz descreve um vagabundo que descansa sob as árvores. $\mathrm{O}$ autor conta igualmente, sob a forma de narrativa retrospectiva intercalada, ora no presente, ora no passado, uma sessão no barbeiro e as conversas dos clientes. "Ele [o mendigo] pensa vaga e incompletamente com seus botões; é Prahins outro dia, Prahins que é barbeiro aos domingos, Prahins, outro dia, no celeiro...”* A narrativa é incessantemente interrompida por finas anotações sensoriais: o barulho do córrego, a libélula que voa. Por essa introdução do tempo da história e 
do presente da narrativa, Ramuz cria o efeito de um fluxo de sensações no qual integra a memória e o pensamento do personagem, designado ora por "ele", ora por "eu": "Ele pensa com uma metade de si./ Engraçado como as coisas se preocupam pouco com você. Cinco dias, cinco dias já”* . É uma das características, em resumo clássica, desses "fragmentos", incluir quase sempre uma parte reflexiva, mas uma reflexão que é atribuída a um personagem e que é dada como sendo a sua própria, saída da sua experiência. "Filosofia" sem conceito, atribuída a personagens simples e comuns, é uma reflexão nascida do contato com as coisas: "Ele levanta seus braços, coloca suas mãos sob sua cabeça: o que somos? qual é a parte de você que é você?’”" . Nesse texto, em que sentir e pensar são considerados indissociáveis, Ramuz mostra a primazia do "existir" do indivíduo percebedor sobre todas as outras atividades do sujeito. E o mendigo "foi como o poeta quando este é abandonado pela poesia"*, o que equivale a dizer que a poesia não é uma atividade reflexiva.

Em Ramuz, a percepção de uma coisa é sempre primeira. Mas esta se junta a um outro nível de existência pela expressão do poeta. "As coisas não existem por si próprias para nós, é preciso que nos sejam ressuscitadas. [...]/ Quando somente este [a figura do artista] diz nomes, e apenas pelos nomes que ele diz, recomeça o mundo para nós"**. O poeta, o escritor ou o artista é não somente aquele que dá conta do mundo, mas também aquele que o oferece, que provoca comunicação entre os homens e as coisas e torna possível a relação entre os indivíduos. Assim se constitui tanto em Ramuz, quanto em outros autores de sua época - Claudel e Péguy, por exemplo - um status social do artista que permanecerá, no entanto, sempre problemático.

Em Création du jour, o propósito se radicaliza: é, pois, de agora em diante, o personagem, não identificado ("Um homem qualquer, qualquer um entre nós.” "), quem cria não somente o dia, como o título indica, mas as coisas. "Vai, no vazio: dele as coisas saem uma a uma. Tira dele as coisas, dispõe-nas em torno de si”*. Aqui novamente a figura do artista e escritor é convocada, figura demiúrgica, que demonstra um poder partilhado, na realidade, por todos.

Um outro mendigo, desta vez em um romance, afirma mais claramente essa função demiúrgica e tética do artista.
(Ramuz, Charles.Ferdi nand. Salutation paysanne et autres morceaux. Genebra: Georg \& Cie, 1921: 114.)

"(: 115) 
" (Ramuz, Charles-Ferdi. nand. CEurres complètes, vol. 3. Ob. cit.: 7.)
" (Robert, Paul. Le petit Robert. Dictionnaire de la lan. gue française, vol. I. Paris: Dictionnaires Le Robert, 1985: 2101.)

"(Ramuz, Charles-Ferdi. nand. "Remarques". Em: CEuvres complètes, vol. 5. Ob cit.: 636.)

"(Merleau-Ponty, Maurice. Phénoménologie de la Perception. Paris: Gallimard, 1945: 376.)
" (Ramuz, Charles·Ferdi nand. CEuvres complètes, vol. III. Ob. cit.: 370-1.)
Em Les Signes parmi nous, romance publicado em 1917, encontra-se o vagabundo esticado sobre um barranco diante da paisagem: "Diante dele estava o monte coberto de videiras; ele levantava o pé: não havia mais videiras./ A grande aldeia que está embaixo, ele levantava o pé: não havia mais aldeia. […]/ Sou eu quem comanda, eu faço, eu desfaço; tiro esta igreja da minha frente quando quiser; as propriedades desaparecem./ Até o céu do bom Deus, contra o qual ajo, se quiser; [....]”*. Notar-se-á nessa passagem o deslize do "ele" ao "eu" na própria narrativa, fenômeno clássico do estilo de Ramuz nessa época. Seja nesse tipo de texto ou em seus romances, ele brinca com o status do narrador, alternando a narrativa mantida por um narrador onisciente e a concentração interna sobre um personagem ou grupo social a que pertence.

Inúmeros críticos evidenciaram, com razão, a importância da visão em Ramuz. Ele mesmo falou da dívida que tinha em relação aos pintores, especialmente a Cézanne, mas também em relação aos pintores de sua geração com os quais tinha ligação. É preciso brincar com o sentido da palavra "visão", isto é, tomá-lo ao mesmo tempo nos sentidos de "percepção do mundo exterior pelos órgãos da visão" e de "representar-se no espírito"*. Para Ramuz "[ [...] as coisas podem ter apenas uma existência interior: e $[\ldots .$.$] aí, isto é, dentro de$ si mesmo [do escritor], há uma paisagem que ele vê [...]”**. É esta visão que o escritor tem de expressar por tarefa. Em termos fenomenológicos, a atitude de Ramuz é aquela descrita Merleau-Ponty em Fenomenologia da percepção: "O que está dado não é a coisa em si, mas a experiência da coisa, uma transcendência num mar de subjetividade [...]."*

Ramuz constrói uma representação interna do país que ele procurará expressar. Essa questão de si e do mundo é colocada, de maneira mais ou menos clara ou difusa, feliz ou problemática, instintiva ou racional, por todos os "personagens" de Salutation paysanne. Um exemplo muito explícito é dado pelo apaixonado que apanha o feno em La faneuse dans son pré*: "Ela olha: é como um outro país que teria diante de si, como um país que não se conheceria; mas será que se conhece melhor o país que se tem dentro de si?”.

Dessa "caixa de imagens" que é o sujeito percebedor (a expressão é do próprio Ramuz e designa o espírito), o escritor constrói uma visão pessoal e original do "país". 


\section{b) O postulado topográfico}

A análise que propomos se fundamenta no estudo de quatro textos de importância particular na obra de Ramuz. Efetivamente, trata-se de quatro textos indispensáveis que se apóiam sobre uma ou outra parte da Suíça romanda, isto é, francófona. O primeiro data de 1908, relativamente cedo na carreira de Ramuz (seu primeiro romance foi publicado em 1905), e os outros são dos anos 1930 e 1940, época de sua consagração.

Os locais que Ramuz descreve são vários: o Valais, arquétipo do vale alpino europeu, a região de Vaud, situada à margem do lago que forma o Ródano, um dos grandes rios europeus, e a Suíça romanda, isto é, o conjunto do território francófono.

O estudo do discurso de Ramuz sobre esses pontos é útil: o universo romanesco desse autor se divide quase imparcialmente entre o Valais e a região de Vaud, de tal modo que a crítica fala dos romances "da montanha" e "do lago". Da observação dessas regiões, Ramuz extrai uma concepção sociológica e política de "país" que se constrói não abstratamente, mas de forma perceptível e aparente, o que não o impede de reunir sob certos aspectos as concepções francesas do nacionalismo. Isso justificaria, se fosse necessário, que se levassem em consideração esses textos, mesmo que eles apresentem alguns aspectos de "guia turístico" e "defesa nacional" que hoje podem parecer engraçados.

No primeiro desses textos, Le village dans la montagne, Ramuz evidencia o modo de vida seminômade dos camponeses, imposto pela topografia (isto é, as encostas do vale) e pelos dados climáticos. Efetivamente, “[...] ocorre sempre o mesmo nesses países de grandes encostas que se erguem até as geleiras, com seus planos diversos: e dessas neves até a planície, através dos pastos, depois os primeiros bosques vastos, depois florestas espessas, depois os prados, e os campos, é todo o clima que muda, e com isso sua vida [...]”**.

O segundo elemento destacado é a auto-suficiência alimentícia e econômica dos habitantes. "Pois tudo de que precisam, eles tiram daqui, eles se bastam a si próprios."* A topografia implica essa auto-suficiência: vasto vale alpino, cerrado nas margens por altas montanhas, é um lugar fechado, ao abrigo das mudanças, sem contatos nem trocas com o

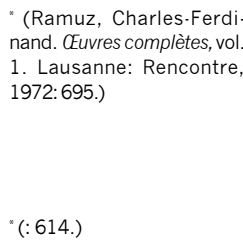




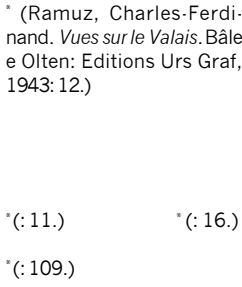

(Ramuz, Charles-Ferdi nand. La Suisse romande. Grenoble: Edition Arthaud 1936: 18.)

"(:83.)

"(:133.) exterior. Ramuz destaca ainda que os habitantes "têm sua própria língua, e somente deles [...]”*, isto é, que cada vale tem seu dialeto.

$\mathrm{O}$ aspecto fechado de Valais é desenvolvido em Vues sur le Valais, escrito 35 anos mais tarde: "E vê-se como este país é feito [...], estando na forma de mezanino alongado, em forma de berço com margens bastante elevadas, tendo uma centena de quilômetros de comprimento, uns quarenta quilômetros de largura; tendo a forma de uma folha, com uma nervura central que é o Ródano [...].”* As imagens são sempre do mesmo tipo, porque o ponto de vista (no sentido próprio da expressão) é sempre de cima: o país é um mezanino, um berço, um "quarto a céu aberto"*, um "imenso bebedouro", um "ninho onde eles [os homens] se seguram"*.

O gosto de Ramuz pelas imagens dominantes se manifesta mais fortemente em seus romances, nos quais os personagens contemplam o país de uma altura ou são descritos ou vistos de cima. Se, como ele diz, a montanha é uma civilização vertical, uma parte de sua obra carrega também essa característica. A crítica ressaltou isso: depois de ter mostrado a importância do olhar e, portanto, da representação em Ramuz, ela evidencia a que ponto esse olhar "de cima" constrói um espaço vertical, polarizado entre o alto e o baixo. $\mathrm{O}$ espaço romanesco é constituído por "planos" que imitam a topografia e que os personagens percorrem e exploram, uma vez que as passagens de um a outro são, ao mesmo tempo, pretexto para a descrição e instrumento dramático.

Esse olhar é aplicado à região de Vaud e à Suíça romanda com as mesmas características: trata-se, no entanto, de um caso mais complexo, de uma superfície mais vasta, mais heteróclita. Mas Ramuz retoma os elementos já mencionados: "É um pequeno mundo fechado. Por todo lado as montanhas o cercam."* Encontram-se imagens próximas das anteriormente evocadas: o país é "uma imensa concha", de novo "uma espécie de berço", um "mezanino de fundo plano"*. Os elementos fundadores de um "país" estão dessa vez explicitamente expressos e organizados:

Diz-se agora o cantão de Vaud; dizia-se outrora o País de Vaud, e a antiga designação tende a ser de novo e cada vez mais empregada. É que cantão não designa mais que uma circunscrição administrativa, enquanto país faz alusão a uma natureza, isto é, a um 
fenômeno físico, que supõe ao mesmo tempo uma certa unidade e um certo equilíbrio na economia de produções. País designa um certo território claramente delimitado e que, graças a seu solo, pode bastar-se a si mesmo. O País de Vaud (é nisso que ele é um país) reconcilia em seu território três climas (o da montanha, o do planalto, o do lago) e três categorias essenciais de cultura: a dos prados e pastos, a do trigo, a do vinho."

A idéia da presença de culturas essenciais (e fortemente simbólicas) em um mesmo país tende a dar a este a dimensão universal que lhe faltava. O país ramuziano é, desde então, um microcosmo perfeito, reunindo e concentrando todos os traços constitutivos de uma civilização. Em Pays de Vaud, Ramuz ressalta também a existência do sal, alimento fundamental que ele acrescenta à lista... O leite, o trigo, o vinho, o sal; uma topografia fechada; climas justapostos ou superpostos; a autarcia: aos olhos de Ramuz, esses seriam os quatro traços principais de um "país" que é verdadeiramente um país.

Para um certo público, Ramuz foi e ainda é considerado o cantor de um mundo rural então em vias de extinção e ainda hoje desaparecido. No entanto, ao olhá-lo de perto, o que o escritor impõe é sua concepção de um país: "Precisava ter um 'país', o meu; inventei-o, é bem possível. [...] Apenas o inventado existe. Nada existe senão na expressão, isto é, a reinvenção, quero dizer a invenção a respeito de alguma coisa"*. A esse respeito, a atenção privilegiada que ele outorga à topografia, em detrimento da história, é reveladora. A história, entretanto, recuperará, dramaticamente, Ramuz: a revolução russa, as duas guerras mundiais, acontecimentos importantes que ele interrogará, sempre valendo-se desse dado de base da geografia.

Se insistimos nesse país recriado, é para mostrar a proximidade, mas também o distanciamento que sua atitude mantém do nacionalismo de Barrès: se este se apóia igualmente no determinismo, Ramuz difere dele por não cair jamais no culto dos mortos, pois sua fidelidade se direciona menos ao patrimônio, ao sangue e ao passado nacional que àquilo que constituiria o ser universal, um indivíduo primordial considerado antes de sua pertença nacional. De longe influenciado pela teoria dos climas, que ele adapta bastante livremente, Ramuz divide o espaço segundo os eixos simples da
"(Ramuz, Charles-Ferdi. nand. "Lettre à Henry-Louis Mermod". Em: CEuvrescom plètes, vol. 3. Ob. cit.: 1242.) 
(Ramuz, Charles-Ferdi. nand. "Besoin de grandeur". Em: CEuvres complètes, vol. 4 Ob. cit.: 951.)

(Ramuz, Charles-Ferdi. nand. Lettres, 1919-1947 Lausanne: Les Chantres, 1959: 324.)

"(Ramuz, Charles-Ferdi nand. "Le grand printemps". Em: CEuvres complètes, vol. II. Ob. cit.: 661-2.)

"(Ramuz, Charles-Ferdinand. A propos de tout. Genebra: Slatkine, 1986: 214.)

(Ramuz, Charles-Ferdinand. "Questions". Em: CEuvres complètes, vol. 4. Ob. cit. 771.) horizontalidade e da verticalidade, dimensões diferentemente valorizadas. O horizontal é definido mais pela superfície, pela extensão quase ilimitada, pelo acaso e pela contingência. A dimensão vertical é mais sujeita ao limite, à necessidade, ao essencial. Ramuz cria então diferenças ontológicas, por assim dizer, entre o habitante das planícies, mais servil, mais receptivo e acomodado, e o homo alpinus, mais isolado e, portanto, menos aberto à mudança. Assim como outras ideologias, o marxismo, segundo Ramuz, "nasceu nas planícies"* e jamais poderia ter prosperado nos vales montanhosos. Em contato permanente com uma natureza imperiosa, as "civilizações verticais" lêem seu destino com uma clara evidência. A verticalidade à qual ele se prende inverte e concentra as propriedades climáticas da horizontalidade, com uma baixa altitude temperada e mediterrânea e uma alta, fria e setentrional: quem evolui nesses planos habita, assim, um continente em si, completo, com várias latitudes.

Esse simbolismo elementar permite classificações e comparações. Por exemplo, Ramuz insiste primeiro sobre as diferenças desse tipo quando se endereça ao tradutor de suas obras em húngaro: "Somos um país de montanhas altas e a Hungria, creio, essencialmente um país de planícies”*. Mas as homologias podem também transcender as diferenças e Ramuz instala um paralelo preferencialmente audacioso entre a imensa Rússia vermelha e o pequeno país conservador de Vaud. Já que os dois países se apóiam sobre um substrato camponês, Ramuz se considera competente para falar do comunismo: a ideologia de Marx não é mais teórica, incorporou-se numa classe que ele pensa conhecer, a dos camponeses, a qual pode interpelar como parente próximo: "Vaudois, saúdo aqui a Rússia, como um pequeno irmão, uma grande irmã”; "O país de Vaud, por si só, é uma pequena Rússia”*. Os eixos horizontal/vertical regem igualmente a oposição cidade/campo com o sistema de valores próprio: essencialmente rural e pouco industrializado, o mundo da verticalidade abriga um certo "rousseauismo", uma autenticidade que não é exatamente a do bom selvagem, mas a do ser universal, em luta muitas vezes direta com as questões primordiais. Desde então, tendo em vista que "a maioria dos homens na Europa vive nas cidades”, o conjunto do continente é particularmente ameaçado por uma modernização que apenas pode 
distanciá-lo da preocupação existencial, da metafísica primitiva, da condição do homem contingente.

Determinadas pelo solo e pela topografia, as populações formam raças que se distinguem menos pelo sangue e pela hereditariedade que, se é possível dizer assim, pelo vigor, compreendido como uma marca metade cultural, metade biológica. Entre parênteses, Ramuz diferencia bem os significados de raça e, especialmente, aquele que Hitler impõe, mostrando que o paradoxo do nazismo é ser racista, ao passo que a própria Alemanha é tão pouco de "castiça", ou seja, é impura, mestiça.

\section{2) A história da Europa}

Um dos traços permanentes das numerosas raças que dividiram entre si os diversos relevos da Europa é o conflito, a competição. A Europa é um campo de tensões permanentes, e a guerra constitui a marca do ser humano. Próximo aqui do velho Heráclito, Ramuz pensa que "o homem sempre esteve em estado de guerra" e que "o estado de guerra é seu estado natural”*. Em 1922, Ramuz publica um romance intitulado La séparation des races, confrontando duas comunidades que ocupam os lados opostos de uma montanha e que se distinguem pela língua e pela religião. A ação do romance confirma o veredicto lapidário do título e destaca a falta de entendimento intercultural e religioso. A rivalidade instintiva das raças todavia não é apenas uma triste fatalidade: analisando bem, ela não está distante, às vezes, de depender da necessidade. Para compreender esse sentimento, é preciso remontar à concepção que Ramuz tem de povo, uma noção para ele mais constitutiva que aquela, política e artificial, de Estado. Tratando-se do povo, ele não parece ter verdadeiramente ultrapassado a idéia romântica e vitalista de um Michelet ou dos românticos alemães ou franceses. O povo constitui para ele uma reserva de autenticidade e até mesmo, às vezes, de inocência, da qual uma das virtudes seria proteger contra o nivelamento, a negligência e a mestiçagem, não física (pois esta, para Ramuz, é efetiva na Europa), mas cultural.

Como outros intelectuais e artistas contemporâneos seus, o Ramuz anterior à Primeira Guerra Mundial traduz no campo da antropologia as leis físicas da termodinâmica: o mundo e as diferenças se resfriam, a degradação e a indife"(Ramuz, Charles-Ferdi-
nand. "Besoin de grandeur".
Ob. cit.: 913.$)$ "(Ramuz, Charles.Ferdi.
nand. A propos de tout. Ob. cit.: 80.) 
(Ramuz, Charles-Ferdinand. "Les grands moments du $\mathrm{XIXe}$ siècle français". Em: CEuvres complètes, vol. 2. Ob. cit.: 897.)

(Ramuz, Charles-Ferdinand. A propos de tout. Ob. cit.: 55 .

"(Ramuz, Charles-Ferdinand. "Les grands moments du XIXe siècle français". Ob. cit: 897.)

"(Ramuz, Charles-Ferdinand Lettres, 1919-1947. Ob. cit.: 169.) rença ameaçam. Essa globalização antecipada se chamava na época "cosmopolitismo" ou "internacionalismo", e não basta dizer que a atitude de nosso escritor é mais inquieta que a de seu caçula Cendrars: "Esses últimos anos antes da Guerra ofereceriam ainda o espetáculo (caso se quisesse realmente assisti-lo) de um internacionalismo político e científico que parece definitivamente produzir, como conseqüência, a negação de uma arte ou de uma literatura que teriam como elementos essenciais serem representativas de uma raça e de uma civilização"*. Ou, ainda, mais cruamente: "o cosmopolitismo invasor vai necessariamente nos obrigar a nos defender"*. Segundo os fatos, o início da Guerra de 1914-1918 é às vezes compreendido como uma força regeneradora, como um caos criador, capaz de restaurar os valores de uso laminados pelos valores de troca que o mundo industrial tende a impor. Com o tempo, a guerra cavalheiresca e heróica se afunda nas trincheiras, acaba em carnificina, levando Ramuz a nuançar suas posições: "é, dramaticamente, em pleno internacionalismo que o princípio das nacionalidades, que se acreditava morto, ergue-se novamente e precipita a Europa e o universo no mais gigantesco dos conflitos"*.

\section{3) A missão francesa da Europa}

Para criticar o que Ramuz pensou sobre a Europa política, é preciso descrever a ótica pela qual ele a considera: seu ponto de vista é determinado pela França, por uma certa idéia da França. Suas representações são pouco políticas, o que se traduz por um fraco interesse pela atualidade interna francesa, pelos conflitos esquerda/direita, pelos diferentes governos e governantes. Em compensação, sua atitude é comandada pelo que é, para ele, a especificidade francesa, seu messianismo e seu universalismo culturais. A França é, para Ramuz, a metonímia essencial da Europa: "A França é a voz do Ocidente", e esse Ocidente se resume em humanismo e, mais exatamente, na preocupação do ser que revela e traduz a arte. É aparentemente essa magnitude de imagens que explica a relativa indiferença de Ramuz pelos Estados europeus. Se ele falou extensamente do nazismo, do fascismo ou do comunismo, sempre minimizou os próprios Estados políticos. Sintomaticamente, uma de suas descrições da Primeira Guerra Mundial põe em destaque as figuras da cultura e não 
as nações: "Poussin combate Dürer e Wagner, Mussorgsky; o próprio Shakespeare toma partido na luta"*. A prioridade da cultura sobre a política lhe permite igualmente englobar os acontecimentos históricos nos grandes movimentos transnacionais que os transcendem, depois de extrair a eterna missão do Ocidente.

Experimentemos definir melhor essa presumida vocação da Europa.

Quando deixou a América para retornar à Europa, Ortega y Gasset deu uma definição preferencialmente orgulhosa do Velho Mundo. Segundo ele, a Europa era o único continente/abrangente (em castelhano, uma única palavra recobre os dois sentidos) a ter um conteúdo ("A Europa é o único continente que tem um conteúdo")*. Ramuz talvez tivesse acertado essa definição, uma vez que ela instala uma continuidade entre a vocação da Roma antiga e a da França atual: o conteúdo específico da Europa não seria outro senão sua capacidade de civilizar e de trazer a uma dimensão universal (válida para todos) as particularidades e os acontecimentos contingentes ou singulares. Segundo uma fórmula que hoje a francofonia gosta bastante de utilizar, o próprio da cultura francesa - Ramuz acrescenta: da Europa - seria "conciliar o singular e o universal", as culturas e as identidades locais com as preocupações universais, a liberdade de cada indivíduo com a razão coletiva.

Nesse jogo de encaixes metonímicos, o que Ramuz diz de Paris define o poder da França e, assim, o horizonte do Ocidente: "Mas eu te [Paris] nomearei primeiro. Aqui está a definição de ti que é preciso, o mais alto nome e a maior capacidade"**.Aqui, de modo menos enfático, escutam-se ainda os sotaques românticos do messianismo francês de um Michelet ou de um Hugo: "Ô França, adeus! Tu és grande demais para ser apenas uma pátria [...]. Tu és tão grande que, de repente, não vais mais ser. Não serás mais França, serás Humanidade; não serás mais nação, serás onipresença. Estás destinada a te dissolver completamente em esplendor [...] Tu, França, torna-te o mundo"**

Quando Ramuz busca precisar e consolidar essa pretensa vocação européia, uma de suas originalidades é não convocar (em seus esboços de teoria política, ao menos) o outro grande patrimônio do qual, além de Roma, a França seria a herdeira privilegiada: Atenas.

"(Ramuz, Charles-Ferdinand. "Journal". Ob. cit.: 1073.) "(Brague, Rémi. Europe, la
voix romaine. Paris: Criterion, 1992: 122.)

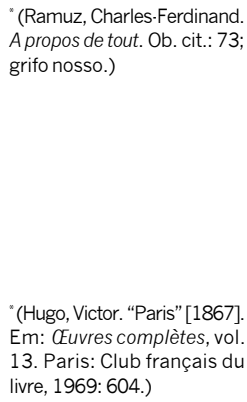

"(Hugo, Victor. "Paris" [1867]. Em: CEuvres complètes, vol. 13. Paris: Club français du livre, 1969: 604.) 
"(Eco, Umberto. "La ligne et le labyrinthe: les structu res de la pensée latine". Em: Duby, Georges [org.]. Civilisation latine, des temps an ciens au monde moderne. Paris: Orban, 1986: 27-57.)

(Ramuz, Charles-Ferdi nand. Citado em Europe, $\mathrm{n}^{\circ}$ 459.60, juillet 1967: 106.)

" (Ramuz, Charles-Ferdi nand. Citado em Europe. Ob. cit.: 110.)

* (: 110.)

"(Ramuz, Charles-Ferdinand. "Le grand printemps". Ob. cit.: 603.)
Os historiadores têm freqüentemente o hábito de ler o trajeto da Europa moderna como uma oscilação entre duas reivindicações ora associadas, ora concorrentes, que são Roma e Atenas. Às vezes, essas referências aparecem na ocasião de conflitos entre nações, como quando a Alemanha nazista quis ser helenista. Fora dessas buscas de paternidade simbólica, entretanto, as referências a Roma e a Atenas podem resumir não mais apenas países e momentos particulares, mas a epistemologia geral da Europa. Foi o que propôs, por exemplo, Umberto Eco, ao definir a Europa como um compromisso entre uma racionalidade romana, caracterizada pela norma, o direito e o espírito analítico, e uma veia grega, mais marcada pela confusão, pelo irracional e pelo sincretismo.*

Em relação a essa tipologia, Ramuz se distingue ao por em evidência não Atenas, porém Bizâncio. "Roma foi um dos sóis, e só se quis ainda ver Roma: a Roma do Oriente que é Bizâncio se eleva, e em torno gira esta enorme obscuridade dos países eslavos"* Consequiência de sua escolha, a cristandade européia (romana e ortodoxa com, evidentemente, todo o substrato bíblico) se vê reforçada e constitui para Ramuz a base do humanismo do continente. Precisemos, no entanto, que a perspectiva de Ramuz não é religiosa, pois a única sacralização que verdadeiramente reivindicou foi a da arte, que substituiu o humanismo cristão e se constrói sobre a superioridade do homem. Desse ponto de vista, se era preciso classificar as religiões, Ramuz as avaliava sempre segundo sua maior ou menor preocupação com o homem. O protestante, que era de nascença, conviveu com o neo-tomismo de um Jacques Maritain, e Pascal foi uma de suas leituras de cabeceira.

Por volta de 1917, sua Europa ideal se apóia, pois, sobre dois pilares, um, francês, já firme e "solidificado", e outro, "ainda em estado gasoso*”, que é o da Rússia, herdeira de Bizâncio, do oriente europeu. Para ele, a França e a Rússia dividem a mesma preocupação primordial do centro, do geral, do humano*. Para Ramuz, Gogol, Tolstoi, Dostoievski ou Mussorgsky foram, portanto, "guias em direção [a ele] mesmo"* e preencheram um papel equivalente ao que ele atribui erroneamente ao conjunto da cultura francesa, o de revelar os indivíduos a si mesmos e à sua própria liberdade. Infeliz- 
mente, o prosaísmo do comunismo e seu humanismo prosaico aplainam todo transcendentalismo e, sobretudo, o único de que ele faz questão, o da arte. Desde então, porque a revolução bolchevique alterou a vocação da Rússia na Europa atormentada dos anos 1930, "não há senão a França"* a ser capaz de assegurar esse poder civilizador. "Pretendo defender a noção de ser contra aqueles que não a têm, papel que me parece dever ser bastante o da França”**.

Observa-se que esse poder está subtendido pelos mesmos preconceitos veiculados por Ortega y Gasset, e ocorre do mesmo modo etnocêntrico, uma vez que atribui à Europa, via França, a prioridade de uma compreensão profunda do ser universal. Como a grande maioria dos intelectuais europeus de seu tempo, Ramuz não imagina a existência de outras formas do universal fora da filosofia européia. Esses preconceitos são ainda mais difíceis de perceber por estarem velados, como de costume, sob a melhor das boas intenções.

A tradução concreta da profunda prioridade humanista da Europa tomou em Ramuz, ao longo dos anos, graus variados: em 1927, depois de uma viagem a Auvergne, ele tem um acesso de paixão violenta (para ir rápido, pois seria necessário precisar a influência de Maritain e descrever a preocupação que ele tem de não se deixar tomar pelo pólo proletário representado por outro de seus correspondentes, o escritor Henri Poulaille), o que o conduz a avaliar excessivamente a capacidade da rusticidade, tal como ele a considera, por conservar a memória do ser essencial*. Por volta do fim de 1943, um outro eretismo o faz atacar "esses porcos americanos/ privados de raça/ privados de solo"*. A agressividade é, entretanto, mais rara que a deploração inquieta diante da perda do contato com o ser. As lamentações de Ramuz não dão razão às ideologias capitalistas e comunistas: "Há, efetivamente, grandes analogias entre o marxismo russo e o capitalismo americano. Um e outro fazem com que sua força, seu esplendor mundial, se baseiem exclusivamente em seu potencial econômico, industrial. [...] A velha Europa, da qual a própria Inglaterra faz parte, vê erguer-se tanto a leste como a oeste a ameaça de um maquinismo excessivo"* Assim, considerando a abstenção incontestável da Rússia, não há senão a França a defender a cidadela do ser e a levantar alto a bandeira do humanismo integral: "Não creio
"(Ramuz, Charles-Ferdinand. Lettres, 1919-1947. Ob. cit: 301.)

*(: 158.)
"(Les Nouvelles Littéraires, 23 août 1945: 2.) 
expressar uma tendência pessoal, mas um sentimento mundial, ao dizer que nossa civilização precisa mais que nunca das forças espirituais, do gênio literário e artístico da França. Se essas incomparáveis fontes se esgotassem, acabaria nosso Ocidente"*.

Essa última frase, aberta pelo "se" hipotético, conduz a um dos últimos planos da visão ramuziana: seu futuro. Quando se deixa imaginar a sorte futura da Europa, fortemente discutida sobre as ruínas de 1945, Ramuz acredita que uma união federalista não é para o dia seguinte, por causa da criação dos dois blocos de influência - americano e soviético. Por mais pertinente que seja, sua atitude deixa novamente manifestar uma relativa indiferença pela vida política, o que se explica pela prioridade que ele concede à esfera estético-ética. Desse ponto de vista, dessa magnitude de visão e de alma, há para Ramuz apenas indivíduos e não mais cidadãos designados por uma ou outra nação. Dito de outro modo, sua Europa de amanhã é uma utopia fundada e garantida pelo consenso que a arte criaria: "resta-nos a elite incomparável de nossos sábios, de nossos artistas, de nossos escritores"*.

\section{4) A Europa e a questão das nações}

Talvez nos espantemos com o pequeno espaço que foi dado até aqui à Suíça. Efetivamente, não seria da pertença nacional que teria sido necessário partir para comentar a Europa de Ramuz, ainda mais pelo fato de que o país, em nome de sua célebre neutralidade, favoreceria um bom ponto de vista? Nesse plano, a opinião de Ramuz é importante, mas em um sentido que poderá surpreender, uma vez que suas críticas sobre a Suíça são as que podem ser as mais construtivas em um plano europeu e, talvez mesmo além dele.

Em 1992, na Exposição Universal de Sevilha, o artista Ben Vautier criou algumas tensões com seu slogan afixado no pavilhão suíço: "A Suíça não existe”. Ele se acreditava original, ignorando - parece - que Ramuz o precedera mais de cinqüenta anos e suscitara uma emoção considerável por ter afirmado mais ou menos a mesma coisa. Em 1937, Ramuz fazia alusão à diversidade da Suíça, que lhe parecia o motivo que a impedia de chegar a uma unidade que lhe bastasse para aspirar a qualquer coesão nacional e a uma expressão, uma cultura suíça. "Como falar da Suíça, que é um país que 
não existe?’*. Ou, ainda, na carta aberta que provocou escândalo: "é cansativa a tarefa de explicar um povo, sobretudo quando ele não existe"*. Todo o país, suspeita-se, foi sacudido e as ondas de choque foram sentidas até o governo. Independentemente das razões profundas de Ramuz, que julgava o país do ponto de vista da expressão artística, sua observação, sua contestação parece útil para nosso próprio tempo e para as formulações atuais sobre a pertença e sobre a identidade.

Tanto nas antigas quanto nas jovens nações de todos os continentes, as buscas de coesão simbólica são hoje fortemente discutidas e todas as atitudes, do nacionalismo arrogante, xenófobo e belicoso ao relativismo nem sempre bem refletido por aqueles que se proclamam "cidadãos do mundo", são representadas. Concretamente, nos anos em que vivemos, o debate na Europa recai sobre o futuro político da união dos quinze países. Certos membros, como a Alemanha, exaltam uma Europa federalista na qual as atuais nações perderiam um pouco de sua individualidade. Outros, como a GrãBretanha e a França, são muito apegados ao conceito de Estado-Nação e temem uma dissolução de suas identidades numa seperestrutura européia.

Nesse debate, a pequena e mesmo involuntária voz de Ramuz (uma vez que sua observação funcionava em um contexto restrito) parece energicamente ir para o lado em que a nação pesa menos. Levando às últimas conseqüências o caso particular que representava a Suíça, Ramuz abria um processo que parece hoje atraente, embora ainda inacabado: liberar o indivíduo de uma concepção arcaica de Estado e de nação. Decerto que Ramuz não foi muito longe e, por exemplo, permanece ainda ligado, como se viu, a uma concepção romântica de povo. No entanto, mesmo parcialmente (pois a sedimentação da identidade e a fixação das raízes não se referem somente à nação), sua desconstrução é particularmente fecunda e heurística.

O interlocutor a quem Ramuz enviou sua carta "escandalosa" sobre a Suíça percebeu bem o positivo sob o negativo aparente. Esse interlocutor, que não é outro senão um dos mais incansáveis construtores da Europa, o ensaísta suíço Denis de Rougemont, declarou, após seu propositor, que a Europa não existia mais. ${ }^{*}$ Em 1958, a observação pertencia à ordem da evidência, certamente. Mas o que Denis de
" ("La Suisse?", Art vivant, juillet 1937.)

"("Lettre", Esprit, n. 61, $1^{\text {er }}$ oct. 1937: 6.) "(Rougemont, Denis de.
"Comment définir l'Euro-
pe ?", conferência em Nice
em 27 de março de 1958. Em:
CEuvres complètes, vol. 3. La
Différence, 1994: 364 -75) 
(Ramuz, Charles-Ferdinand CEuvres complètes, vol. 5. Ob. cit.: 408-9.)
Rougemont considerava, retomando os passos de Ramuz, era a idéia de uma agregação (para ele obrigatoriamente de caráter federalista) que fosse capaz de existir sem unificar e sem fortalecer os nacionalismos. Evidentemente, nesse artigo visionário, Denis de Rougemont não escapava de um certo etnocentrismo, não mais nacional, porém europeu. Acredita-se, contudo, que a pequena divergência com Ramuz permanece na ordem do paradoxo positivo: aquele, assimilado pela crítica a um escritor da terra, foi capaz de pensar para além das culturas pretensamente nacionais. Cada vez menos seu ponto de vista de 1937 é dissonante daquele recentemente fixado na embaixada da Suíça, em Berlim, no momento de sua inauguração: "uma nação é um grupo de pessoas diferentes que partilham suas diferenças”.

\section{Conclusão}

Aproveitemos Histoire du soldat, da qual um excerto nos será proposto em um instante ${ }^{2}$, para resumir nosso trajeto. O próprio script e as lembranças de Ramuz quanto à sua colaboração com Stravinsky nos dão abundante matéria.

Em 1929, Ramuz publica Souvenirs sur Igor Stravinsky. Ele descreve a amizade que o ligou ao compositor, os trabalhos que fizeram juntos, entre 1915 e 1920. Ao evocar sua proximidade com Stravinsky, destaca a espécie de comunhão espiritual que os dois tiveram, encontrando, para além de suas diferenças e de seu respectivo país, o "País", com maiúscula, o "Grande Jardim perdido da unidade". E, por conseguinte, aí está a tarefa designada à arte: reencontrar, "perceber de novo" o grande parentesco dos homens, tal qual Ramuz pôde senti-lo em relação a Stravinsky. Fiel à sua concepção de artista como intermediário, como aquele que revela ao público o singular dos seres e das coisas, no outro extremo, a arte é o que une, reúne os homens para além da pertença nacional e cultural.

O soldado da história é uma das figuras ramuzianas do poeta. Sua função recorda a primazia ou a permanência da struggle for life e da severidade dos tempos. Mas quando o script o põe em ação, o soldado está de licença militar, tor-

\footnotetext{
${ }^{2}$ Os organizadores do colóquio de São Paulo tinham previsto fazer acompanhar esta comunicação de um excerto de História do soldado.
} 
nando-se, então, um errante, um viajante. Como o mendigo, como o operário diarista, é um ser marginal, dividido entre a busca de seu lugar de origem e um nomadismo ontológico, sem laços, sem entraves. Na aventura de 1918, o soldado tenta abandonar seu destino e se deixa seduzir pela fortuna. Vaidade: europeu no sentido em que vimos, ele permanece antes de tudo um personagem do ser e não do ter. Ele tem mais sorte no amor, pois se casa com a princesa que, como Orfeu, curou com o poder de sua arte - nesse caso, de seu violino. Ainda assim, sua felicidade é apresentada como uma espera, pois o personagem é tentado a reencontrar seu pequeno vilarejo e suas raízes. Ora, se ultrapassa a fronteira do retorno, perde sua Eurídice.

Tradução: Roberta Andrade do Nascimento 


\section{Noël Cordonier}

Professor da Haute Ecole Pédagogique de Vaud e Professor assistente da Universidade de Lausanne. Produziu tese e livros sobre Victor Segalen, e pesquisa e artigos sobre vários autores de língua francesa - entre os quais Ramuz -, sobre a didática da literatura e sobre as representações do francês.

\section{Alain Rochat}

É, desde 1997, colaborador científico no Centro de Pesquisas de Letras Romandas. Foi o responsável, sob a direção de Doris Jakubec, pelo inventário, pela classificação e preservação dos manuscritos de C.-F. Ramuz. Desde 1999, coordena os projetos de edição crítica do escritor; participou da edição dos romances de Ramuz na Bibliothèque de la Pléiade (estabelecimento da cronologia, repertório de nomes citados e aparato crítico do romance Terre du Ciel, de 1921).

Palavras-chave
Ramuz
guerra
nação
Key words
Ramuz
war
nation
Mots-clés
Ramuz
guerre
nation

\section{Resumo}

A posição ideológica e política de Ramuz em relação à nação e à Europa se funda em uma poética que deseja exprimir representações de coisas percebidas, exprimir um "país" cuja topografia representa um condicionamento superior à história. Valendo-se desse postulado, Ramuz estabelece diferenças de linhagens, notadamente em função do critério: horizontalidade versus verticalidade.

Para o escritor, a guerra é a marca constitutiva do ser humano, e a Europa, um campo de tensões permanentes, do qual a França representa o pólo civilizador, por encarnar a defesa do ser e do humanismo integral. Fiel à sua atitude inicial, Ramuz privilegia os indivíduos que estariam unidos pelo consenso que a arte criaria, mais do que pela pertença a uma nacionalidade.

\begin{abstract}
Ramuz's political and ideological stance regarding the nation and Europe is based on a poetics purporting to express the representation of things as they are perceived, and to express a "country" whose topography is a determination above history. It is from this postulate that Ramuz establishes differences among lineages, notably following the opposition between horizontality and verticality.
\end{abstract}

\section{Résumé}

La position idéologique et politique de Ramuz par rapport à la nation et à l'Europe se fonde sur une poétique qui veut exprimer les représentations des choses perçues et exprimer un "pays" dont la topographie est un conditionnement supérieur à l'histoire. C'est à partir de ce postulat que Ramuz établit des différences de races, en fonction notamment du critère horizontalité versus verticalité. 
For the writer, war is the constitutive trait of human beings, and Europe is a field of permanent tensions, in which France represents the civilizing pole, embodying the defense of being and thorough humanism. Faithful to his starting point, Ramuz privileges those individuals who would be united through an artcreating consensus, instead of just belonging to a given nationality.
Pour l'écrivain, la guerre est la marque constitutive de l'être humain et l'Europe un champ de tensions permanentes, dans lequel la France représente le pôle civilisateur et incarne la défense de l'être et de l'humanisme intégral. Fidèle à son attitude de départ, Ramuz privilégie les individus qui seraient unis par le consensus que créerait l'art plutôt que par l'appartenance à une nationalité.
Recebido em 31/10/2003 Aprovado em $15 / 03 / 2004$ 